\title{
KAJIAN HIDROLOGI DAN ANALISA KAPASITAS TAMPANG SUNGAI KRUENG LANGSA BERBASIS HEC-HMS DAN HEC-RAS
}

\author{
Ichsan Syahputra ${ }^{1}$ \\ ${ }^{1)}$ Program Studi Teknik Sipil, Fakultas Teknik, Universitas Abulyatama \\ Jl. Blang Bintang Lama Km 8,5 Lampoh Keude Aceh Besar, \\ email: ichsan.syahputra76@gmail.com
}

\begin{abstract}
Krueng Langsa is a river crossing Langsa City the position is in the middle of residential and potentially catastrophic spills seasonal flooding. Krueng Langsa River watershed has an area of $126 \mathrm{~km} 2$, with a rainfall of $2300 \mathrm{~mm} /$ year and includes areas with relatively high rainfall. In the upper part of the river flow characteristics along the hills, while the central part of the narrowing of the river in the extreme. Hydrologic simulation based on rainfall data using HEC-HMS software
\end{abstract}

obtained flood discharge of $59.30 \mathrm{~m}^{3} / \mathrm{sec}$. Passing the analysis of flood discharge capacity obtained on existing cross-section of $60.07 \mathrm{~m}^{3} / \mathrm{sec}$ which is almost close to the value of the existing flood discharge based on the model HEC-HMS. HEC-RAS analysis results with simulation input Q2 years, to 140 pieces of the cross section illustrates that almost all river basins experienced flooding conditions (overflow), and only a few parts that are not experiencing flooding conditions. This is because the flood water level exceeds the elevation of the bank. Scenario flood control is done by normalizing the river, which enlarge the dimensions of the existing river with a wide cross-section of the river on average $20 \mathrm{~m}$ to $60 \mathrm{~m}$ and planning at the river levee embankment crest elevation $+2.00 \mathrm{~m}$ and surveillance (freeboard) $0.50 \mathrm{~m}$ of surface water flooding. At the mouth of the river, starting from the point STA.O + 000 to STA.2+ 000 planned use of the river revetment rock pile (Dump Stone). Both scenarios flood control can be recommended to reduce the flooding that occurred in the Krueng Langsa river.

Keywords : HEC-HMS, Passing Capacity, HEC-RAS, Normalisasi Sungai

\begin{abstract}
Abstrak: Sungai Krueng Langsa merupakan sungai melintasi Kota Langsa dimana posisinya berada di tengah-tengah pemukiman penduduk dan luapannya sangat berpotensi menimbulkan bencana banjir musiman. Sungai Krueng Langsa memiliki luas DAS $126 \mathrm{~km}^{2}$, dengan curah hujan $2300 \mathrm{~mm} /$ tahun dan termasuk daerah dengan curah hujan yang relatif tinggi. Pada bagian hulu alur sungai tersebut memiliki karakteristik yang menyusuri perbukitan, sedangkan bagian tengah terjadi penyempitan sungai secara ekstrim. Simulasi hidrologi berdasarkan data curah hujan dengan menggunakan software HEC-HMS didapatkan debit banjir sebesar 59.30 $\mathrm{m}^{3} /$ detik. analisis Passing capacity didapatkan debit banjir pada penampang existing sebesar $60.07 \mathrm{~m}^{3} /$ detik yang hampir mendekati nilai debit banjir existing berdasarkan model HECHMS. Hasil analisa HEC-RAS dengan simulasi input Q 2 tahun, terhadap 140 buah cross section memberikan gambaran bahwa hampir semua alur sungai mengalami kondisi banjir (luapan), dan hanya beberapa bagian saja yang tidak mengalami kondisi banjir. Hal ini disebabkan karena elevasi muka air banjir melebihi elevasi bank. Skenario pengendalian banjir dilakukan dengan cara normalisasi sungai, yaitu memperbesar dimensi penampang sungai existing dengan lebar dasar sungai rata-rata $20 \mathrm{~m}$ menjadi $60 \mathrm{~m}$ dan perencanaan tanggul sungai pada elevasi puncak tanggul $+2.00 \mathrm{~m}$ dengan tinggi jagaan (freeboard) $0.50 \mathrm{~m}$ dari muka air banjir. Pada bagian muara sungai, yaitu mulai dari titik STA.0+000 sampai STA.2+000 direncanakan menggunakan revetment sungai dari tumpukan batu (Dump Stone). Kedua skenario pengendalian banjir tersebut dapat direkomendasikan untuk mereduksi banjir yang terjadi pada sungai Krueng Langsa.
\end{abstract}

Kata Kunci : HEC-HMS, Passing Capacity, HEC-RAS, Normalisasi Sungai. 
Bencana banjir menjadi fenomena rutin di musim penghujan yang merebak di berbagai daerah aliran sungai (DAS) di sebagian besar wilayah Indonesia. Jumlah kejadian banjir dalam musim hujan selama beberapa tahun terakhir terus meningkat demikian juga dengan jumlah korban manusia dan kerugian harta benda termasuk sarana dan prasarana umum/sosial, transportasi dan pertanian/pengairan. Selain masalah curah hujan sebagai faktor penyebab, timbulnya bencana juga tidak terlepas dari adanya kerusakan ekosistem lingkungan yang terjadi di daerah aliran sungai (DAS) dan buruknya pengelolaan sumberdaya air. Adanya kerusakan lahan menyebabkan meningkatnya koefisien aliran permukaan semakin besar. Daerah hulu DAS akan semakin rentan terhadap kekeringan, sebaliknya daerah hilir justru rentan terhadap banjir, seperti yang terjadi pada sungai Krueng Langsa.

Sungai Krueng Langsa merupakan sungai yang berada di Kota Langsa dimana posisinya berada di tengah-tengah Kota Langsa. Krueng Langsa terbentang dari Desa Pondok Kemuning, Desa Suka Rakyat, Desa Geudubang, Desa Seulalah, Desa pondok Pabrik, Desa Sidodadi, Desa Sidorejo, Desa Meurandeh, Desa Baroh Langsa Lama dan bermuara di Desa Alue Beurawe. Posisi sungai yang berada di tengah kota dan disamping pemukiman penduduk sangat berbahaya dan berpotensi sebagai sumber bencana berupa bencana banjir musiman.

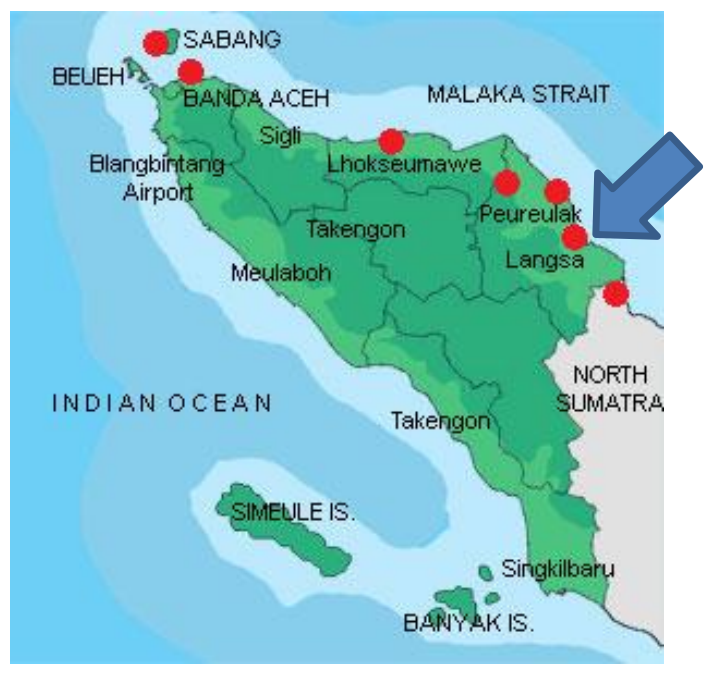

Gambar 1. Peta Lokasi Kajian

Sungai Krueng Langsa memiliki luas DAS $\pm 126 \mathrm{~km} 2$ dengan curah hujan 2300 $\mathrm{mm} / \mathrm{tahun}$ dan termasuk daerah dengan curah hujan yang relatif tinggi. Alur sungai pada bagian Hulu Krueng Langsa memiliki karakteristik menyusuri perbukitan yang sempit, pada bagian tengah terjadi penyempitan sungai dengan membentuk alur yang ekstrim. Pada bagian hilir ke arah muara di kiri kanan sungai terdapat area tambak, sungai yang besar berkelok-kelok dan banyak terdapat alur-alur sungai mati serta mengecilnya sungai muara di bagian hilir.

Berdasarkan permasalahan yang terjadi di atas, diperlukan analisa hidrologi untuk kajian terhadap debit banjir eksisting yang pernah terjadi di wilayah DAS tersebut serta perlu dianalisa kapasitas penampang sungai Krueng Langsa sebagai upaya untuk mendapatkan alternatif pengendalian banjir secara menyeluruh dan mereduksi muka air banjir.

Untuk menganalisis kondisi hidrologi dengan menggunakan perangkat lunak HEC- 
HMS, sedangkan untuk menganalisis kehandalan kapasitas sungai terhadap debit banjir rencana dilakukan dengan menggunakan perangkat lunak HEC-RAS.

\section{KAJIAN PUSTAKA}

\section{Normalisasi Alur Sungai dan Tanggul}

Normalisasi sungai merupakan usaha untuk memperbesar kapasitas dari pengaliran dari sungai itu sendiri. Penanganan banjir dengan cara ini dapat dilakukan pada hampir seluruh sungai di bagian hilir. Faktor-faktor yang perlu pada cara penanganan ini adalah penggunaan penampang ganda dengan debit dominan untuk penampang bawah, perencanaan alur yang stabil terhadap proses erosi dan sedimentasi dasar sungai maupun erosi tebing dan elevasi muka air banjir.

Pembuatan Flood Way dimaksudkan untuk mengurangi debit banjir pada alur sungai lama dan mengalirkannya melalui flood way.

\section{Pembuatan Retarding Basin}

Pada pembuatan Retarding Basin, daerah depresi sangat diperlukan untuk menampung volume air banjir yang akan datang dari hulu, untuk sementara waktu dan kemudian melepaskan kembali saat banjir surut. Penanganan banjir dengan cara ini sangat tergantung dari kondisi lapangan.

\section{Waduk Pengendali Banjir}

Waduk yang mempunyai faktor tampungan yang besar berpengaruh terhadap aliran air di hilir waduk. Dengan kata lain waduk dapat merubah pola inflow-outflow hidrograf. Perubahan outflow hidrograf di hilir waduk biasanya menguntungkan tehadap pengendalian banjir yang lebih kecil dan adanya perlambatan banjir. Pengendalian banjir dengan waduk biasanya hanya dapat dilakukan pada bagian hulu dan biasanya dikaitkan dengan pengembangan sumber daya air.

Fungsi waduk untuk pengendali banjir agar mendapatkan manfaat yang lebih besar harus didesain atau dilengkapi dengan pintu pengendali banjir, sehingga penurunan debit banjir di hilir waduk akan lebih besar atau perubahan antara inflow dan outflow hidrograf yang besar.

Alokasi volume waduk untuk pengendali banjir berbanding lurus dengan penurunan outflow hidrograf banjir di hilir waduk atau dengan kata lain semakin besar volume waduk maka semakin besar pula penurunan outflow hidrograf banjir di hilir waduk.

Operasional dan pemeliharaan dari waduk yang mempunyai pintu pengendali banjir memerlukan biaya yang besar tetap akan menurunkan atau memperkecil biaya normalisasi dan pemeliharaan dari sungai di bagian hilir waduk

Untuk memjaga keandalan dari pintu pengendali banjir sebaiknya pengoperasian dari pintu pengendali banjir dilakukan secara otomatis dan dilengkapi dengan operasi secara manual (untuk keadaan darurat)

Pada waktu multi purpose perlu adanya analisa inflow-outflow hidrograf untuk 
mengetahui seberapa besar pengaruh waduk terhadap debit banjir di hilir waduk

Diperlukan penelusuran banjir atau flood routing yang dimaksudkan untuk mengetahui karakteristik hidrograf outflow atau keluaran yang sangat diperlukan dalam pengendalian banjir.

\section{Debit Banjir Rencana}

Banjir adalah terjadinya luapan air dari alur sungai. Banjir terjadi karena volume air yang mengalir di sungai persatuan waktu melebihi kapasitas pengaliran alur sungai, sehingga menimbulkan luapan. Debit banjir adalah besarnya aliran sungai yang diukur dalam satuan (m/dtk) pada waktu banjir. Debit banjir rencana adalah debit maksimum dari suatu sungai yang besarnya didasarkan kala ulang atau periode tertentu.

\section{Model HEC-HMS}

Beberapa model hidrologi yang telah dikembangkan untuk menganalisis proses hidrologi sebagai komponen daur hidrologi, hubungan hujan-limpasan, dan pembangunan sumber daya air adalah model SSARR, Stanford Model IV, model DawdyO'Donnell, model SCS, model Sacramento, model TOPOG (Indah, 2003). Sementara itu US. Army Corps. of Engineers banyak mengembangkan model HEC (Hydrologic Engineering Centre) untuk keperluan analisis hidrologi. Salah satu model hidrologi yang dikembangkan adalah HEC-HMS (Hydrologic Modelling System). Program ini merupakan versi yang lebih baru dari program HEC-1 dan berbasis Graphical User Interface (GUI).

Model hidrologi dengan program HECHMS dirancang untuk mensimulasikan proses hujan-limpasan dari sistem aliran. Program ini dirancang agar dapat diaplikasikan dalam luasan tertentu untuk merepresentasikan proses hidrologi DAS (Pitocchi dan Mozzali, 2001).

Program ini terintegrasi dengan sistem database, sehingga data dapat dimasukan secara manual maupun melalui DSS (Data Storage System). DSS digunakan sebagai interface antara berbagai model yang terintegrasi dan juga antara komponen yang ada dalam program HEC-HMS untuk memudahkan sistem operasi.

Program ini terdiri dari tiga komponen yaitu model basin, model hidrologi dan kontrol spesifikasi. Keluaran model ini didapat berupa hidrograf limpasan dalam suatu sistem hidrologi DAS yang dilengkapi dengan hidrograf limpasan pada setiap SubDAS pada sistem hidrologi tersebut.

\section{Model HEC-RAS}

Analisa hidrolika sungai dimaksudkan untuk menganalisa profil muka air banjir dengan berbagai kala ulang dari debit banjir rencana. Analisa hidrolika akan menghitung seberapa jauh pengaruh pengendalian banjir secara struktural terhadap tinggi muka air banjir dan luapan banjir yang terjadi. 


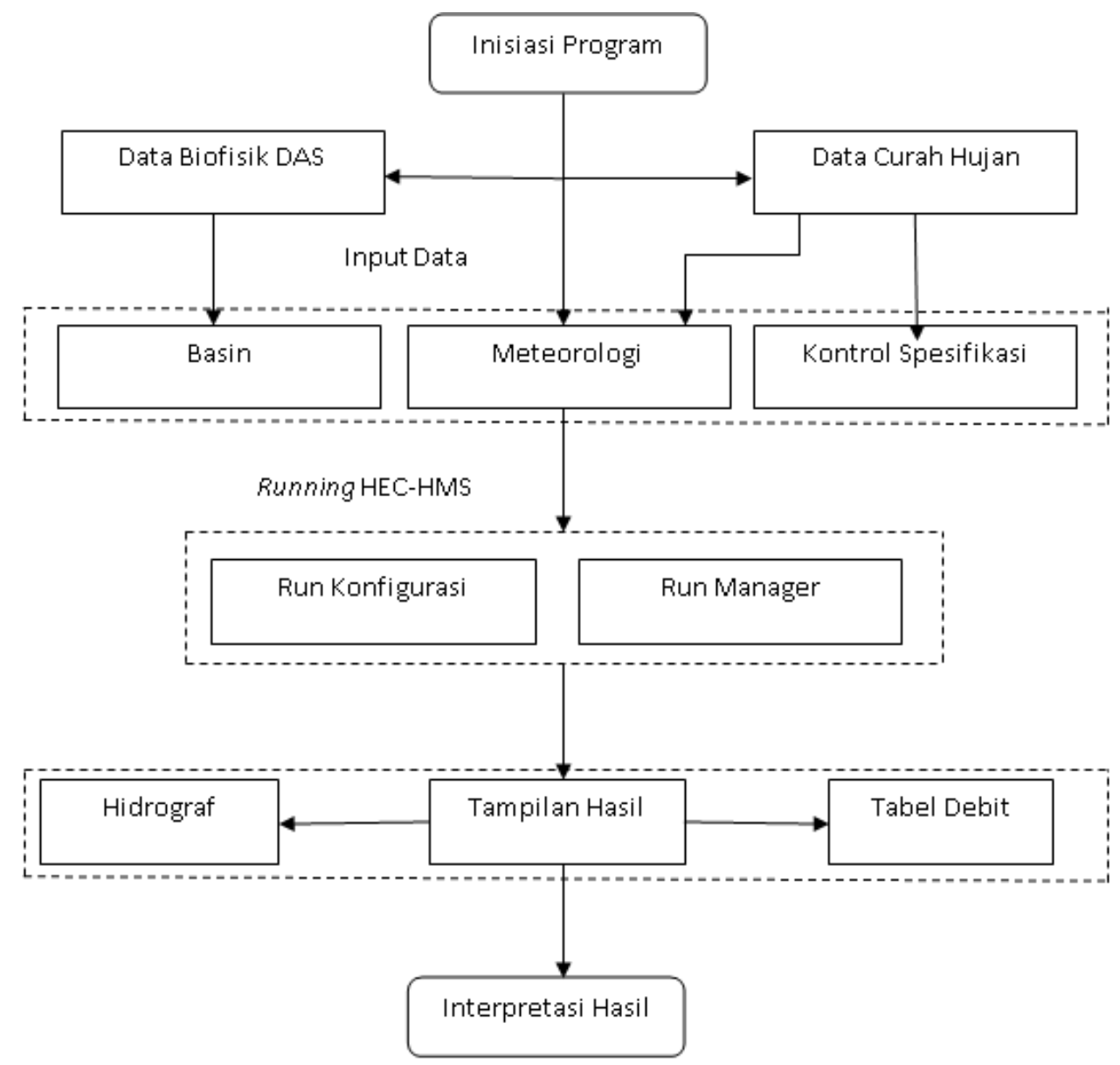

Gambar 2. Diagram Alir Model Hidrologi HEC-HMS

Model hidrolika aliran satu dimensi yang banyak digunakan saat ini ialah HECRAS (River Analysis System) (Pitocchi dan Mozzali, 2001). Program HEC-RAS adalah sebuah program yang didalamnya terintegrasi analisa hidrolika, di mana pengguna program dapat berinteraksi dengan sistem menggunakan fungsi Graphical User Interface (GUI). Program ini dapat menunjukkan perhitungan profil permukaan aliran mantap (steady), termasuk juga aliran tak mantap (unsteady), pergerakan sedimen dan beberapa hitungan desain hidrolika. Dalam terminologi HEC-RAS, sebuah pengaturan file data akan berhubungan dengan sistem sungai. Data file dapat dikategorikan sebagai berikut: plan data, geometric data, steadyflow data, unsteady flow data, sediment data dan hydraulic design data.

\section{METODE PENELITIAN}

\section{Curah Hujan}

Data curah hujan diperlukan untuk mendapatkan hidrograf debit banjir rencana. Data curah hujan yang digunakan untuk perhitungan adalah data curah hujan harian maksimum tahunan. 


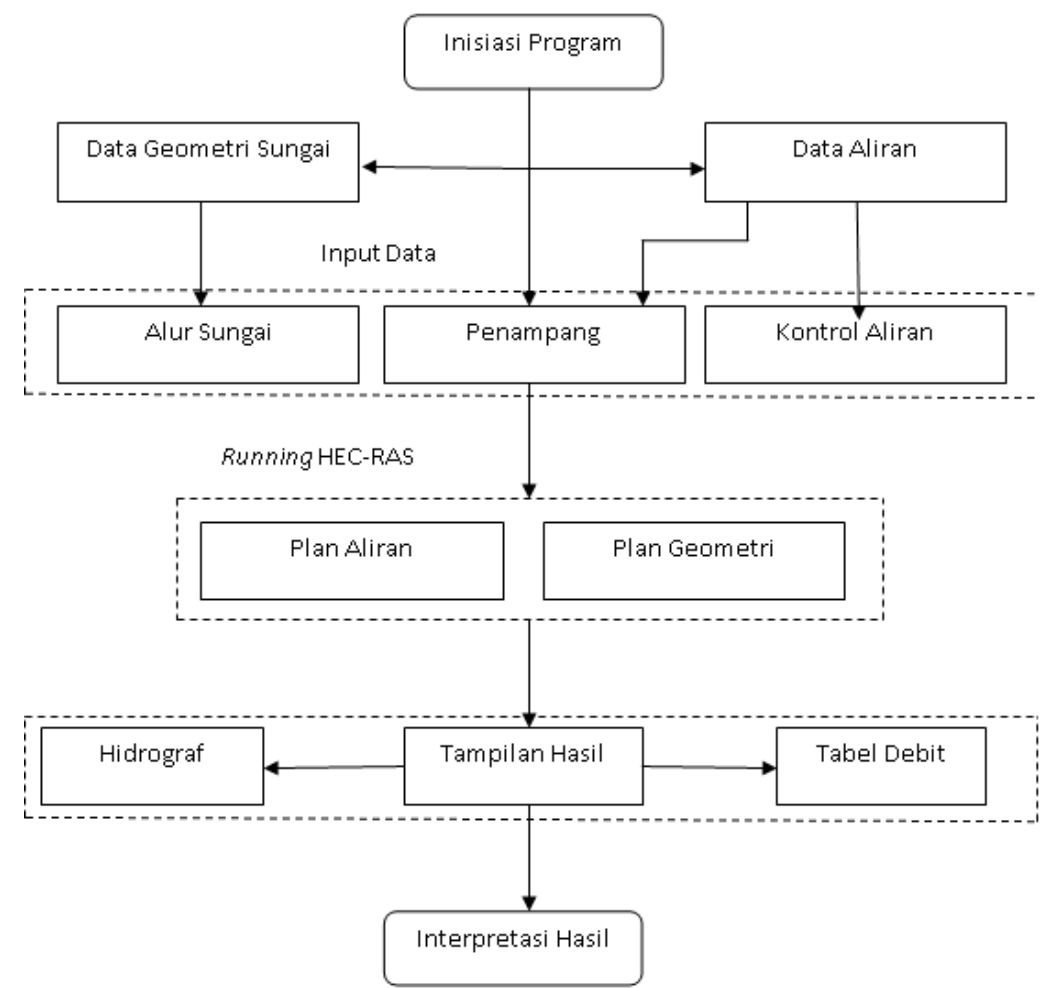

Gambar 3. Diagram Alir Model Hidrolika HEC-RAS

Dikarenakan tidak adanya data hujan terbaru yang tercatat dari stasiun pencatatan di PTP I Kebun Pulau Tiga di Kabupaten Aceh Timur, maka dipakai data curah hujan dari tahun 1981 - 1996.

\section{Geometri sungai}

Geometri sungai diperlukan untuk mendapatkan penampang sungai secara horizontal dan vertikal, sehingga data tersebut dapat mendukung analisa hidrolika.

\section{Hidrologi}

Analisa hidrologi yang sering dilakukan adalah estimasi kejadian banjir maksimum, terutama karena perencanaan dan perancangan sumber air dan manajemen banjir tergantung dari frekuensi dan besarnya puncak aliran debit. Model HEC-HMS dan metode Passing Capacity dapat digunakan untuk memperkirakan besarnya debit banjir rencana.

Model HEC-HMS mengemas berbagai macam metode yang digunakan dalam analisa hidrologi. Dalam pengoperasiannya menggunakan basis sistem windows, sehingga model ini menjadi mudah dipelajari dan mudah untuk digunakan, tetapi tetap dilakukan dengan pendalaman dan pemahaman dengan model yang digunakan.

Di dalam model ini, terdapat beberapa macam metode hidrograf satuan sintetik. Sedangkan untuk menyelesaikan analisis hidrologi ini digunakan hidrograf satuan sintetik dari SCS (soil conservation service) dengan menganalisa beberapa parameternya, maka hidrograf ini dapat disesuaikan dengan kondisi di Pulau Sumatera dan daerah pengaliran Sungai Krueng Langsa pada 
khususnya. Sebagai pembanding,

berhubungan dalam jaringan yang dicantumkan perhitungan debit banjir rencana dengan metode Passing Capacity.

\section{Model HEC - HMS}

Representasi fisik daerah tangkapan air dan sungai terdapat dan tersusun pada basin mensimulasikan sebuah proses limpasan permukaan langsung (run off). Elemenelemen yang digunakan untuk mensimulasikan limpasan adalah subbasin, reach, junction, dan reservoir

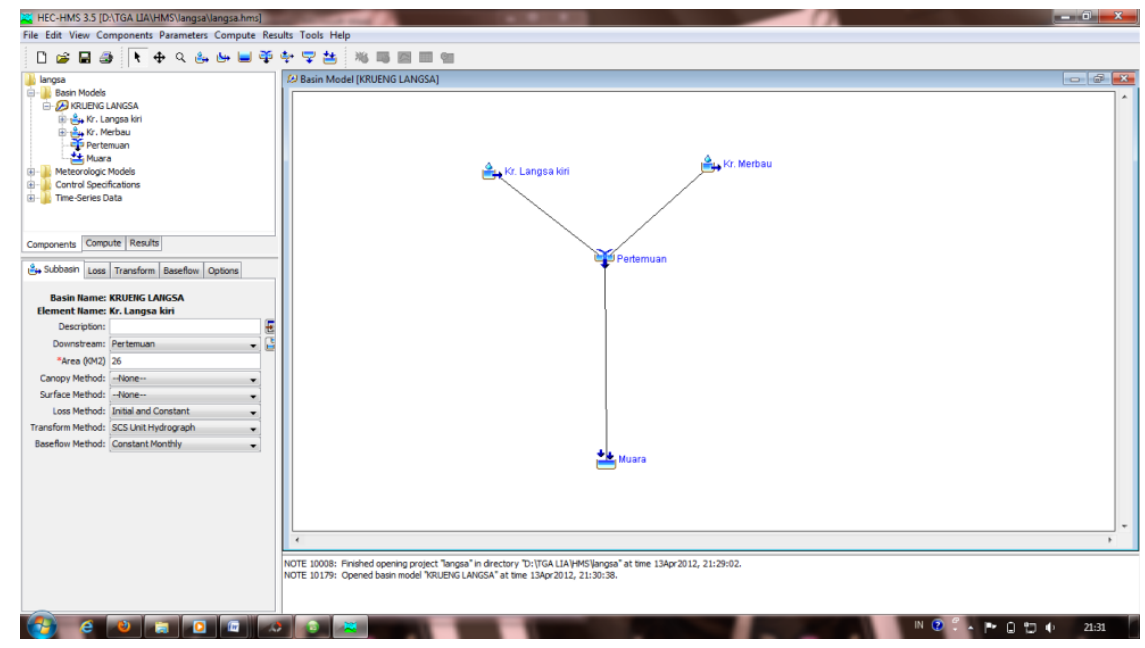

Gambar 4. Skenario Model HEC-HMS

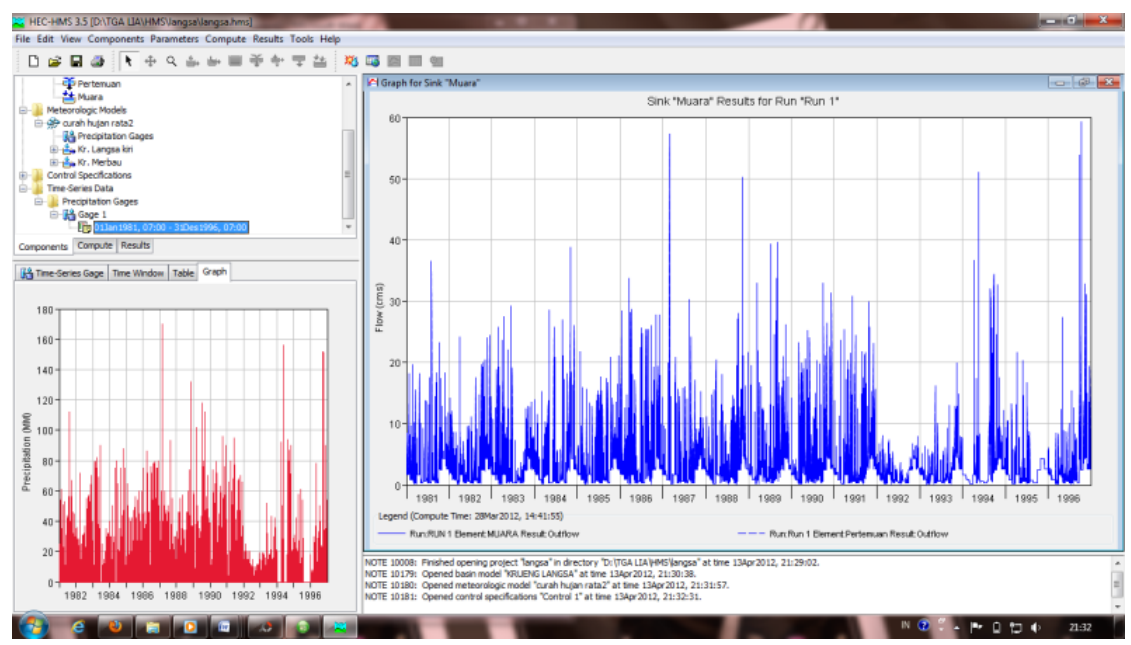

Gambar 5. Grafik Rainfall-Rainoff

\section{Passing Capacity}

Metode passing capacity digunakan sebagai kontrol terhadap hasil perhitungan debit banjir rencana yang diperoleh dari data curah hujan.

Volume 1, No. 1, Januari 2015

\section{Model HEC-RAS}

Dalam analisis hidrolika karakteristik sungai sangat diperlukan untuk analisis kapasitas pengaliran, kecepatan aliran, profil muka air, kondisi aliran dan fenomenafenomena lainnya. Perhitungan hidrolika 
dihitung dengan menggunakan software HEC-RAS.

Outflow pemodelan sungai berupa elevasi muka air banjir untuk setiap debit rencana. Ouput pemodelan sungai berupa elevasi muka air banjir untuk setiap debit rencana. Selanjut dilakukan skenario pengendalian banjir, yaitu metode reduksi muka air banjir rencana. Analisa pemodelan sungai menggunakan HEC-RAS adalah perhitungan steady flow dengan Metode Standard Step. Output elevasi muka air banjir diperoleh melalui profile plot dari hasil simulasi.

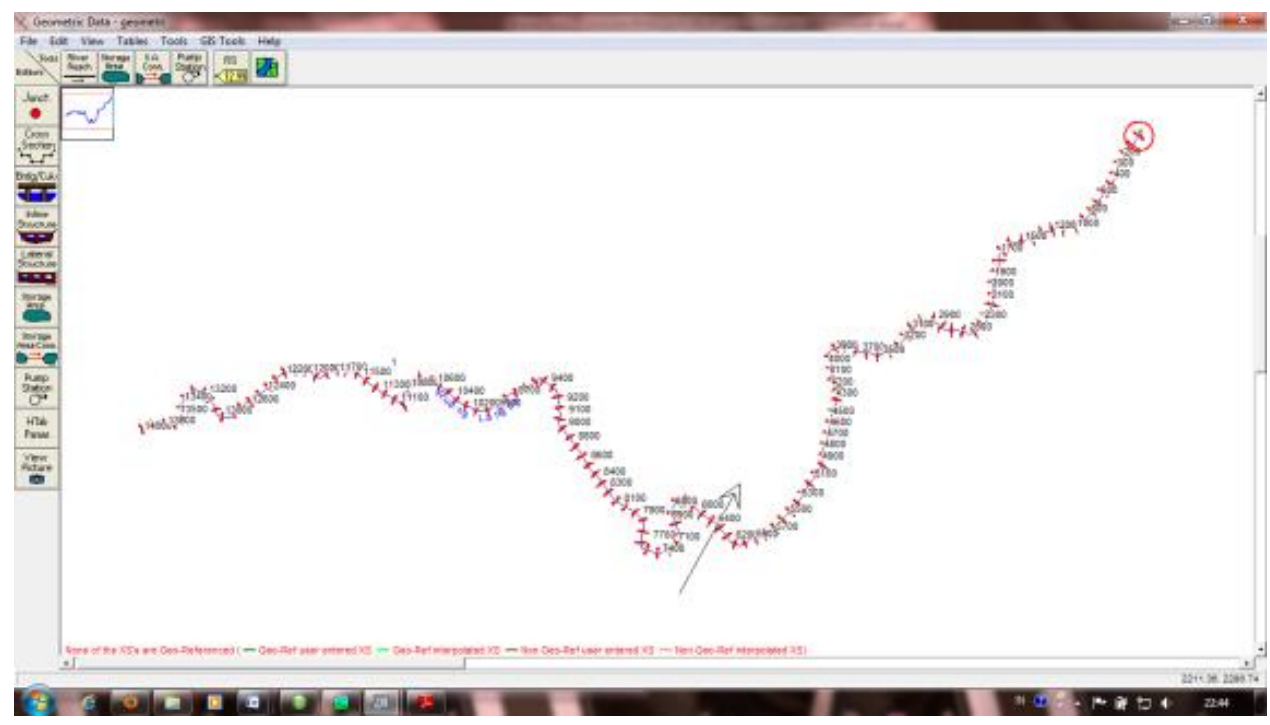

Gambar 6. Skematis Kondisi Sungai

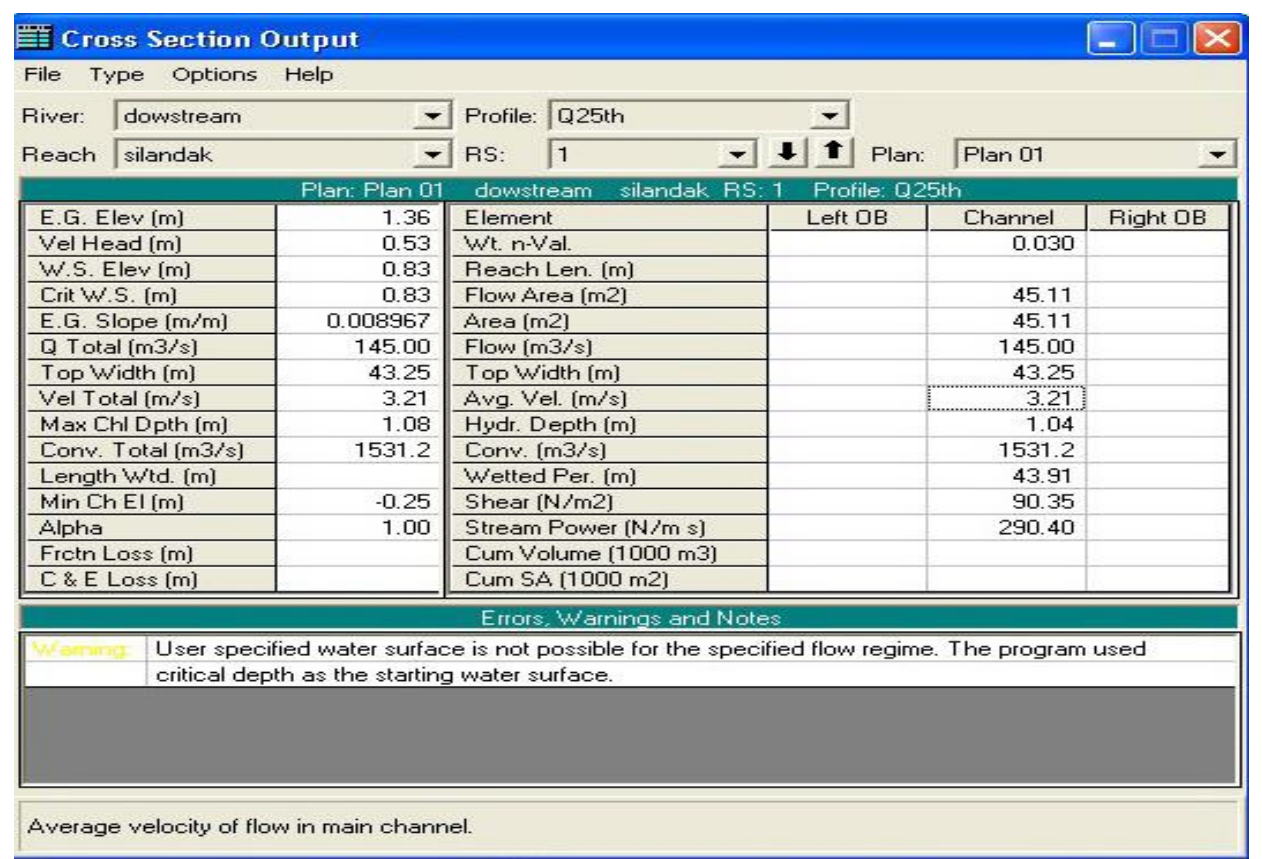

\section{Gambar 7. Data Output HEC-RAS}




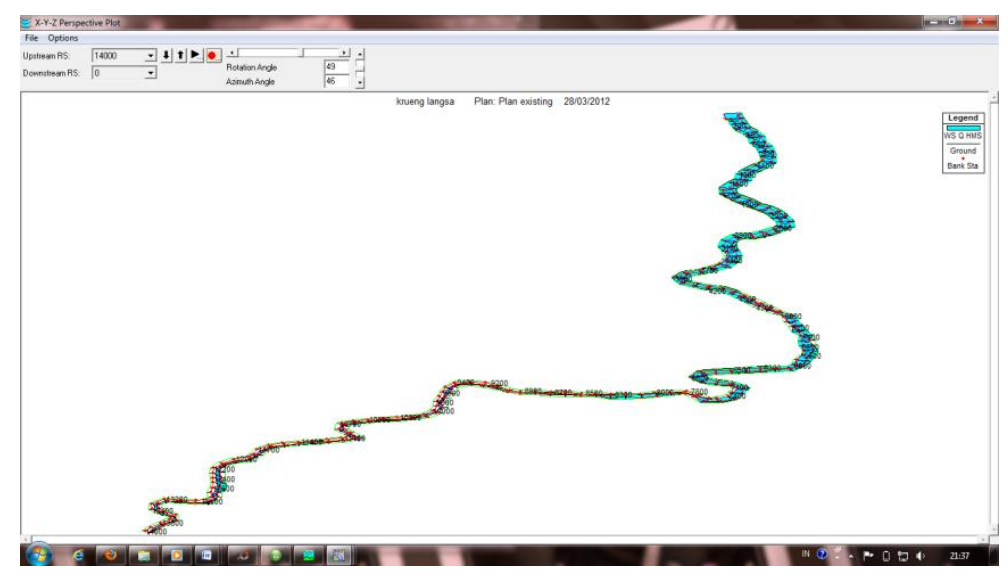

Gambar 8. Profil Sungai Output HEC-RAS

\section{Alternatif Pengendalian Banjir}

Normalisasi sungai terutama dilakukan berkaitan dengan pengendalian banjir, yang merupakan usaha untuk memperbesar kapasitas pengaliran sungai. Hal ini dimaksudkan untuk menampung debit banjir yang terjadi untuk selanjutnya disalurkan ke sungai yang lebih besar atau langsung menuju ke muara/laut, sehingga tidak terjadi air limpasan dari sungai tersebut.
HASIL PEMBAHASAN

Analisa Hidrologi

Dalam analisis ini ada beberapa data yang digunakan dalam perhitungan dan disesuaikan dengan tujuan yang akan dicapai dan data tersebut disesuaikan dengan fungsinya. Data curah hujan adalah data hujan yang terjadi pada suatu daerah akan sampai ke palung sungai setelah mengalami penguapan. Data hujan diambil yaitu data curah hujan harian dan bulanan (Joesron dan Soewarno,1993).

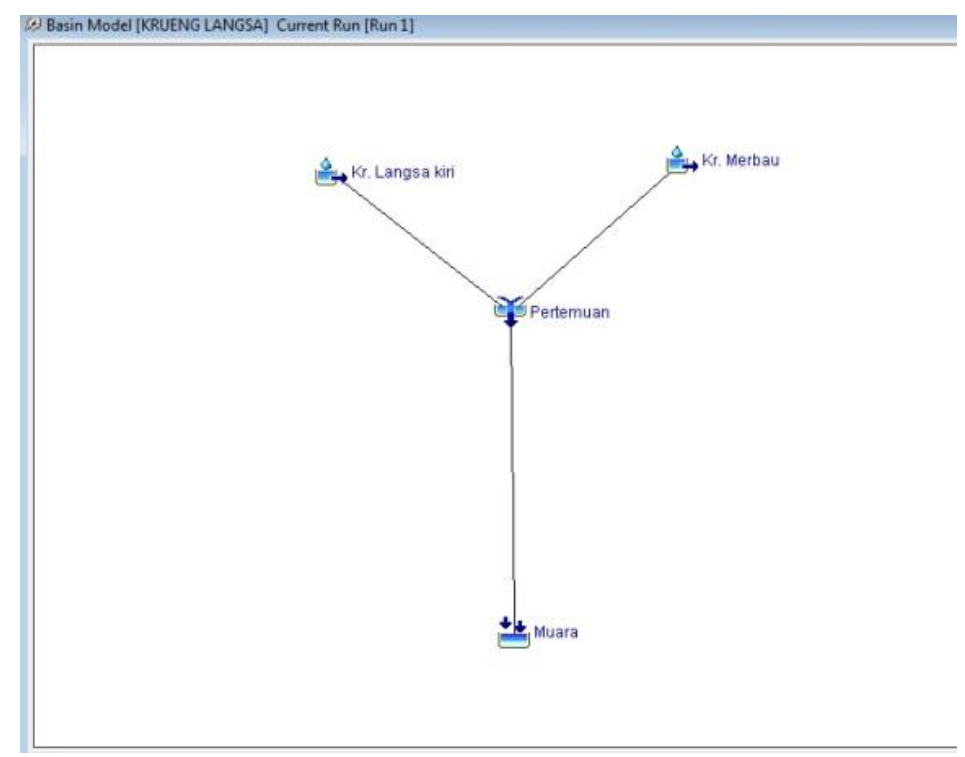

Gambar 9. Skematis Model DAS Krueng Langsa

Volume 1, No. 1, Januari 2015 
Data hujan yang digunakan untuk lokasi kajian yaitu menggunakan pos penakar hujan PTP I Kebun Pulau Tiga di Kabupaten Aceh Timur, karena pos penakar hujan tersebut dianggap dapat mewakili dan terdekat dengan lokasi studi dengan data curah hujan 16 tahun pengamatan (1981-1996).

\section{Debit Banjir Rencana Dengan Model HEC-HMS}

Dari hasil eksekusi data dengan menggunakan metode HEC - HMS dengan periode ulang 2 tahun diperoleh debit banjir rencana sebesar $59.30 \mathrm{~m} 3 /$ detik.
Pemodelan dengan menggunakan HEC - HMS dapat dilakukan kalibrasi dengan menggunakan data hitungan nilai dengan menggunakan metode Passing Capacity sehingga dapat disimulasikan debit banjir yang mendekati sebenarnya.

\section{Analisa Penampang Eksisting Dengan Passing Capacity}

Perhitungan dengan metode Passing Capacity digunakan rumus manning untuk aliran uniform, karena sungai dianggap sebagai saluran terbuka dengan perhitungan seperti pada Gambar 12.

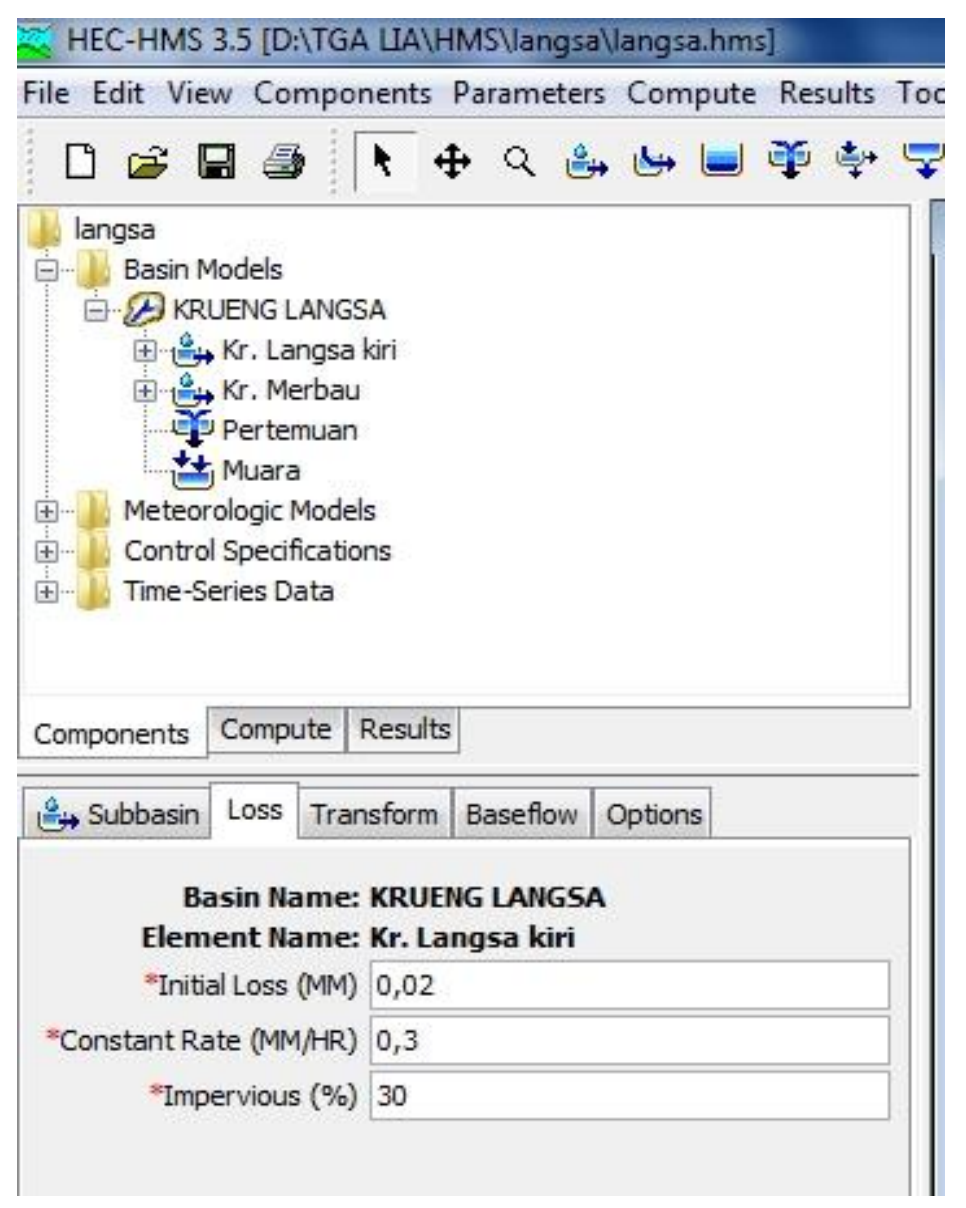

Gambar 10. Input Model DAS Krueng Langsa 


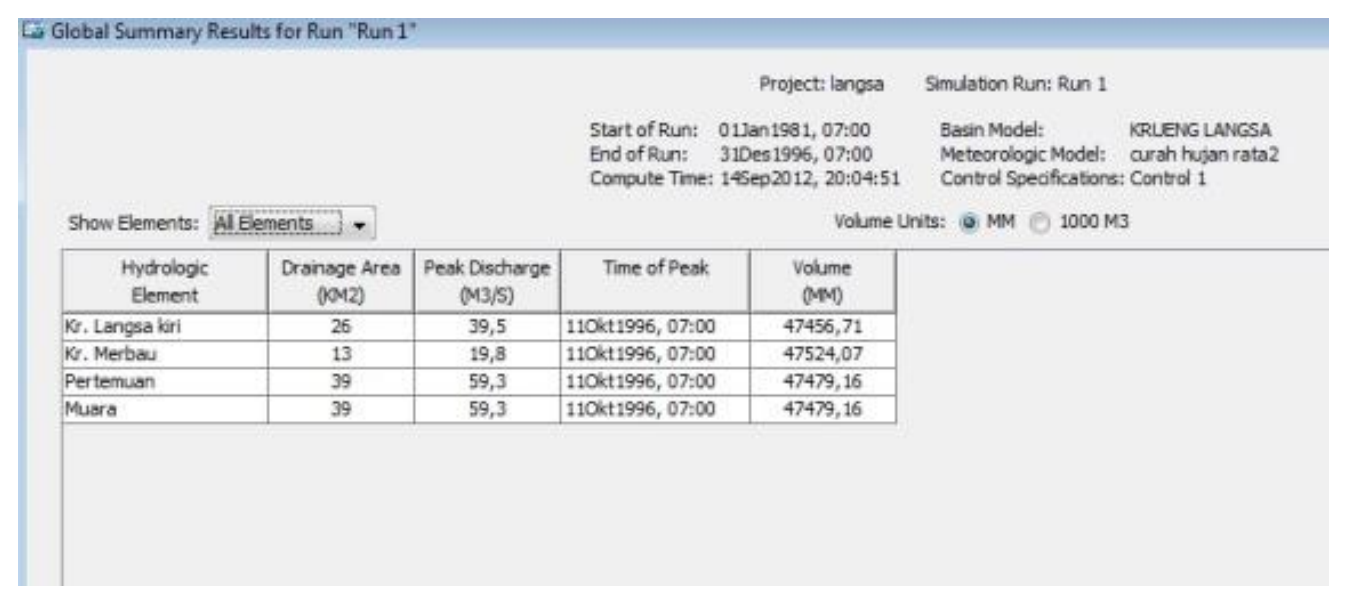

Gambar 11. Output Banjir Periode Krueng Langsa

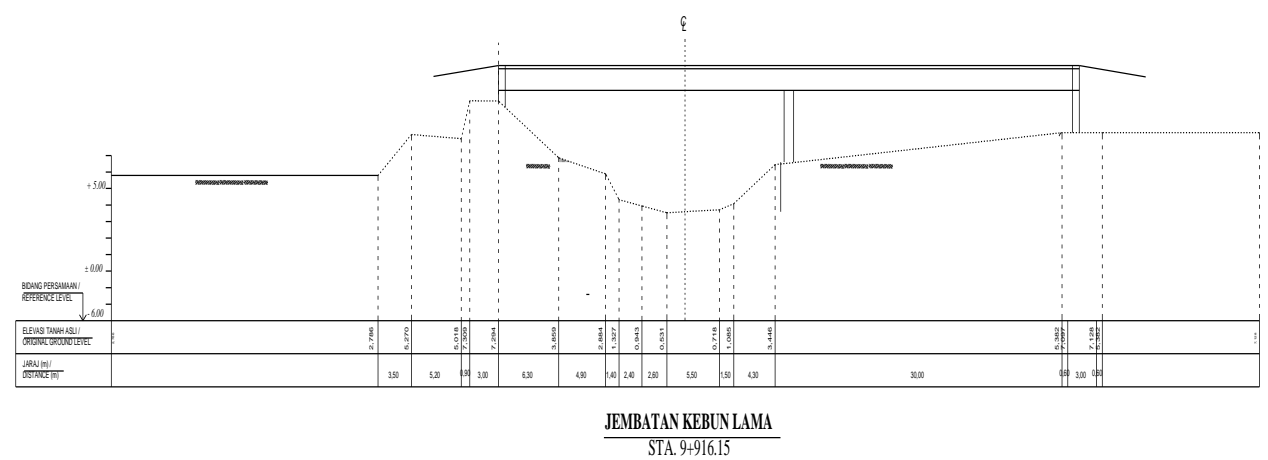

Gambar 12. Penampang Eksisting Jembatan Krueng Langsa

Hasil perhitungan dengan metode Passing

Capacity sebagai berikut :

Slope $=0.00038$

$\mathrm{n}=0.025$

Luas Penampang main chanel sungai :

$\mathrm{A}=38.02 \mathrm{~m} 2$

Jari-jari Hidrolis main chanel sungai :

$\mathrm{R}=\mathrm{Hmax}$

$\mathrm{R}=2.91 \mathrm{~m}$

Kecepatan main chanel sungai :

$\mathrm{V}=1.58 \mathrm{~m} 3 / \mathrm{det}$

Debit Main Chanel sungai :

$\mathrm{Qu}=\mathrm{A} \cdot \mathrm{V}$

$\mathrm{Qu}=38.02 .1 .58$

$\mathrm{Qu}=60.07 \mathrm{~m} 3 / \mathrm{det}$
Dari hasil perhitungan diatas dapat dilihat bahwa alur sungai hanya mampu menampung debit sebesar $60.07 \mathrm{~m} 3 / \mathrm{dt}$, dengan tinggi muka air $2.91 \mathrm{~m}$. tinggi jagaan yang disyaratkan sebesar 0.50 meter. Berdasarkan ketetapan dari DIRJEN Sungai, nilai debit yang didapatkan melalui Passing Capacity adalah Q 2.3 tahun dan termasuk kedalam Q rencana periode ulang 2 tahun. Kondisi diatas memperlihatkan bahwa sungai existing sekarang tidak dapat menampung debit banjir tahunan yang sering terjadi, hal ini diperparah dengan kondisi bantaran yang dipenuhi dengan rumah penduduk dan kondisi sungai yang berkelok-kelok. 


\section{Analisa Hidrolika Dengan Model berdasarkan data pasang surut air laut yaitu: \\ HEC-RAS \\ Analisa dilakukan dengan meng-input data kondisi Steady Flow. Perhitungan pada ruas sungai dari muara (downstream) yaitu dengan panjang sungai $14 \mathrm{~km}$ ke arah upstream, yaitu stasiun 254. Analisa dilakukan dengan tiga kondisi eksisting \\ Menginput data pasang surut $+1.50 \mathrm{~m}$ ( kondisi HWL / High Water Level) \\ Menginput data pasang surut $+0.75 \mathrm{~m}$ (kondisi MSL / Mean Sea Level) \\ Menginput data pasang surut $\pm 0.00 \mathrm{~m}$ ( kondisi LWL / Low Water Level)}

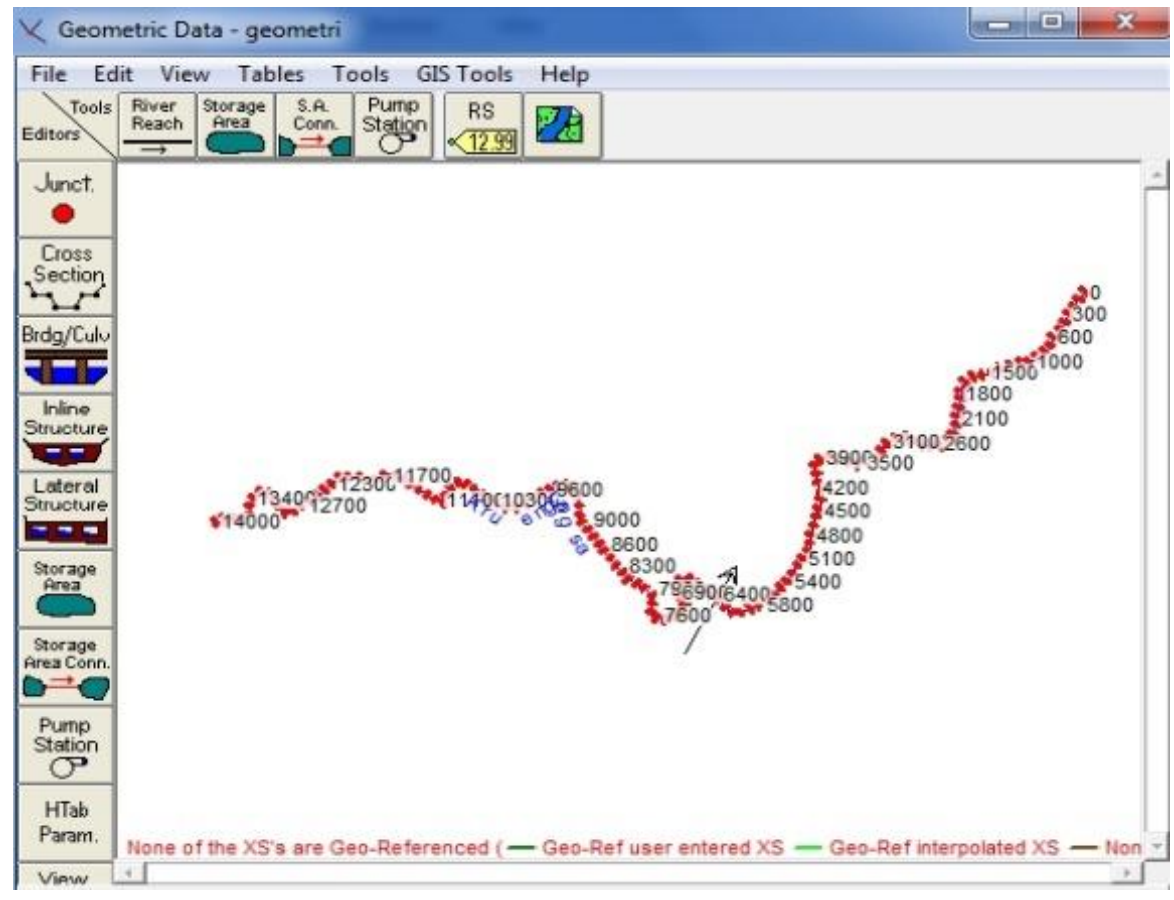

Gambar 13. Skematisasi Sungai Krueng Langsa

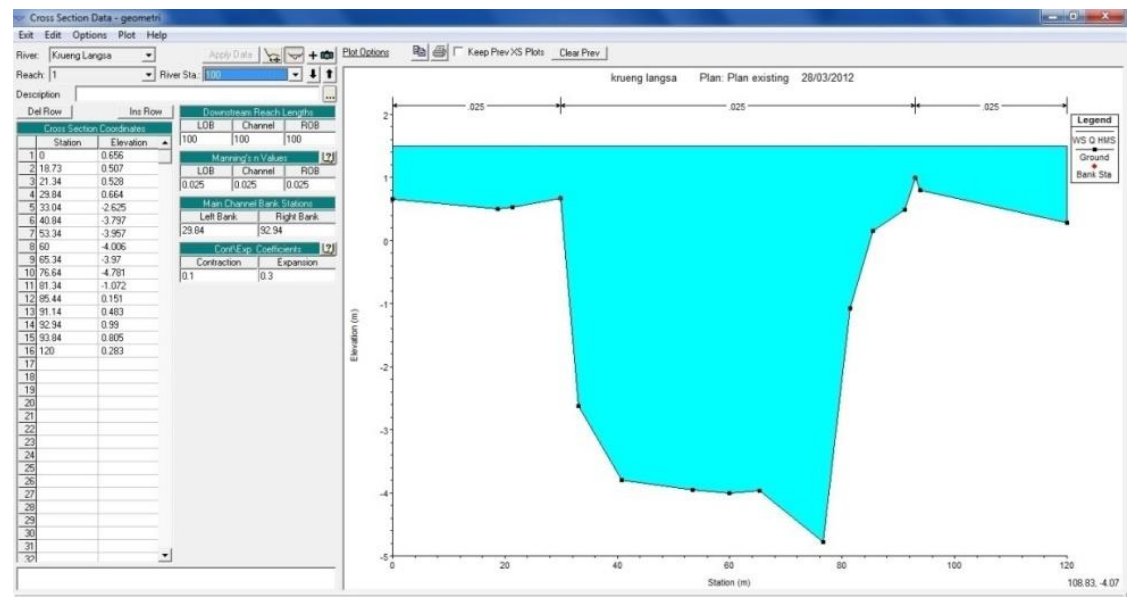

Gambar 14. Geometri Sungai Krueng Langsa 
Kondisi eksisting yang dipakai sebagai analisa pengendalian banjir dipakai kondisi existing High Water Level dengan muka air di penampang hilir sungai $+1.50 \mathrm{~m}$. Kondisi ini dianggap sebagai kondisi paling extrim pada penampang sungai Krueng Langsa dimana dari hasil analisa didapatkan di sebelah kiri dan kanan tanggul banjir sungai (bank station) terjadi luapan, yaitu sta 0+000 dari muara hingga sta $8+300$ ke arah hulu sungai.

\section{Pengendalian Banjir Dengan Normalisasi Sungai dan Tanggul}

Normalisasi sungai terutama dilakukan berkaitan dengan pengendalian banjir, yang merupakan usaha untuk memperbesar kapasitas pengaliran sungai. Hal ini dimaksudkan untuk menampung debit banjir yang terjadi untuk selanjutnya disalurkan ke sungai yang lebih besar atau langsung menuju ke muara/laut, sehingga tidak terjadi air limpasan dari sungai tersebut.

Normalisasi sungai dilakukan dengan cara memperbesar dimensi penampang sungai existing dengan lebar dasar sungai rata-rata $20 \mathrm{~m}$ menjadi $60 \mathrm{~m}$, namun hal tersebut tidak mampu menampung debit banjir yang terjadi pada saat pasang surut tertinggi terjadi di muara yang menyebabkan sebagian penampang sungai masih meluap.

Untuk mengantisipasi kondisi tersebut maka direncanakanlah tanggul sungai dengan elevasipuncak tanggul $+2.00 \mathrm{~m}$ dengan tinggi jagaan (freeboard) $0.50 \mathrm{~m}$ dari muka air banjir. Pada bagian muara sungai, yaitu mulai dari titik STA.0+000 sampai STA.2+000 direncanakan menggunakan revetment sungai dari tumpukan batu (Dump Stone).

\section{KESIMPULAN DAN SARAN \\ Kesimpulan}

Kesimpulan yang dapat diambil dari studi penanggulangan banjir yang telah dilakukan ini adalah :

1. Debit puncak di outlet Sungai Krueng Langsa sebesar 59,3 m³/dt untuk periode ulang 2 tahun.

2. Pada analisa Passing capacity, didapatkan banjir penampang existing sebesar 60,07 $\mathrm{m} 3 /$ det.

3. Hasil analisa HEC-RAS dengan simulasi input Q 2 tahun, terhadap 140 buah cross section memberikan gambaran bahwa hampir semua alur sungai mengalami kondisi banjir (luapan), hanya beberapa bagian saja yang tidak mengalami kondisi banjir. Hal ini disebabkan karena elevasi muka air banjir melebihi elevasi bank.

4. Skenario pengendalian banjir dilakukan dengan cara normalisasi sungai, yaitu memperbesar dimensi penampang sungai existing dengan lebar dasar sungai ratarata $20 \mathrm{~m}$ menjadi $60 \mathrm{~m}$ dan perencanaan tanggul sungai pada elevasi puncak tanggul $+2.00 \mathrm{~m}$ dengan tinggi jagaan (freeboard) $0.50 \mathrm{~m}$ dari muka air banjir.

5. Pada bagian muara sungai, yaitu mulai dari titik STA. $0+000$ sampai STA. $2+000$ 
direncanakan menggunakan revetment sungai dari tumpukan batu (Dump Stone).

\section{Saran}

Saran yang dapat diberikan berdasarkan studi pengendalian banjir yang telah dilakukan ini adalah :

1. Studi hidrologi yang dilakukan harus lebih detail yang berkaitan dengan jumlah stasiun hujan, panjang waktu pengamatan, dan data hujan yang terbaru akan menghasilkan hasil studi yang lebih baik.

2. Skenario pengendalian banjir untuk suatu daerah hendaknya dilakukan dengan beberapa skenario, hal ini untuk memilih bangunan yang paling cocok sesuai dengan kondisi banjir daerah tersebut.

3. Penulis mengharapkan untuk kedepannya akan ada Penulis-penulis lain yang mengkaji skenario pengendalian banjir lainnya pada sungai Krueng Langsa seperti pembuatan alur pengendali banjir (Floodway), pembuatan Retarding Basin, dan waduk pengendali banjir.

\section{DAFTAR PUSTAKA}

Anonim 1, 2011, Laporan Akhir DED Krueng Langsa, PT. Meiditama Indokonsult, Banda Aceh

HEC, 2002, HEC RAS Application Guide, US Army Corps of Engineers, Davis, California.

HEC, 2002, HEC RAS Hydraulic Reference Manual, US Army Corps of Engineers, Davis, California.
Kodoatie, R.J. dan Roestam Sjarief. 2005. Pengelolaan Sumber Daya Air Terpadu. Yogyakarta: Andi.

Loebis Joesron.1984. Banjir Rencana Untuk Bangunan Air, Bandung

Sholeh M. 1998. Hidrologi I. Diktat Kuliah. Surabaya : FTSP -ITS

Sofia F , 2000. Teknik Sungai, Diktat kuliah, Surabaya : FTSP-ITS

Soemarto,CD. 1999. Hidrologi Teknik. Jakarta : Penerbit Erlangga

Sosrodarsono S, dan Tominaga M, 1984. Perbaikan dan Pengaturan Sungai. Jakarta : PT Pertja

USACE. 2000. Hydrologic Modelling System HEC HMS Technical Reference Manual. Maret 2000. http://www.hec.usace.army.mil.

USACE. 2002. Hydrologic Modelling System HEC. 